\title{
Design of PVT System for Typical Indian Village and its Analysis for the Reduction of Co2 Emission
}

\author{
Mohammed Danish Iqbal \\ Department of Mechanical Engineering \\ IEC Engineering College \\ Noida, India \\ e-mail: md.danish200@gmail.com
}

\author{
Ijlal Ahmad Rizvi \\ Assistant Professor, Department of Mechanical Engineering \\ IEC Engineering College \\ Noida, India \\ e-mail: ijlalrizvi.me@ieccollege.com
}

\begin{abstract}
This dissertation work outline is that by using Solar Photovoltaic (SPV) System in typical Indian villages, how we can remove the $\mathrm{CO}_{2}$ emissions. Requirement of PVT system is calculated according to the actual energy demand of a village population and its impact on CO2 reduction is assessed. It is, therefore, important to consider the possibility of utilizing the renewable energy resources, which do not degrade the environment. It is a well-known fact that the average living standard of rural population is lower than that of urban population. One way of improving the living standards is to provide better energy facilities. This will also check the migration of population from rural to urban area. This migration causes social and economic imbalances and is, there on, not desirable.
\end{abstract}

Keywords: Village Energy Scenario, Energy Requirement, Design Analysis of PV System, Calculation of PV System, Calculation of CO Emissions and its Saving

$* * * * *$

\section{Introduction}

Energy analysis of a typical Indian village has been carried out by adopting the net energy analysis (NEA) model for using the household appliances like TV, CFL, LED and Fan by selected families. India is one of the most established civic establishments with a mixed variety of culture and areas. It has accomplished multi-layered socio-economic advancement among the most recent 71 years after freedom. There has been a general pattern of rise in per capita GDP just as energy utilization. Essential business energy supply has been indicated almost $8.2 \%$ growths in GDP against Government focus of $19 \%$. There is different purpose behind this; the most unique reason is the absence of a sufficient energy arrangement and arranging. These days getting ready for energy requests isn't just a satisfactory energy supply yet additionally thought of environmental contamination. The energy assumes a prime job in the economicdevelopment, mechanical advancement and human's welfare. Energy is basic part of the rural development process. The energy capability of country goes about as an indicator of its economic growth. A solid and productive energy supply and energy utilization design is essential, especially with regards to powerful utilization of decentralized sustainable power sources. [1]

The zap is ordinary where the power generation is finished by hydro, coal, gas, and diesel. This has the typical antagonistic effect on the environment. The $\mathrm{CO}_{2}$ outflows are required to increment because of power generation by normal sources. It is in this manner Important to think about using the sustainable power sources, which don't degrade the environment. It is verifiable truth that the normal expectation for everyday comforts of rural population is lower than that of urban population. One method for improving the expectation for everyday comforts is to give the better workplace. This will also check the movement of population from rural to urban region. This relocation causes social and economic difficult nature.

It is evaluated that India has 6.38 Lakh villages, however so far 6.04 lakh Indian villages has been charged., the rest are yet to be energized. As per the govt. plans, charge of village must be finished in the decade's time. About $73 \%$ of the Indian population lives in rural region. It is along these lines imperative to analyses the example of energy usage in rural population and dependent on this analysis, the proposal for improving the situation should be worked out. [2]

\section{THE VILLAGE SELECTED FOR STUDY}

Sherpur is a small Village in Rahui Block in Nalanda District of Bihar State, India. It comes under Sherpur Panchayath. It belongs to Patna Division. It is located 9 KM towards North from District headquarters Bihar Sharif. $65 \mathrm{KM}$ from State capital Patna.

Sherpur village is a typical rural settlement. The major activity of the population is agriculture. Population of Sherpur village is 1545 . In Sherpur out of total population, 835 were engaged in work activities. $81.23 \%$ of worker describe their work as main work (employment or earning more than six month) which is $18.77 \%$ were involved in marginal activities providing livelihood for less than six months. Out of 835 
workers, 288 were cultivator (owner or co-owner) while 547 were agriculture laborer. The standard of living of these people is typical rural, the activities are more or less subsistence oriented which is against rural, the activities of Indian per capital GNP. on an average $69 \%$ of the land is under cropping two times a year. The cropping season is well defined which specific crops are raised.[3]

Crop like paddy, wheat, corn, mustard, tobacco and vegetable are grown. The main source of aggregation is canal \&tube wells about $12.31 \%$ of the households are totally landless. Some of them are engaged in carpentry, black smith, tailoring, basket making, day pottery, masonry work, bricks kiln, etc. The main features of the village are sown in table given below.

Table - 1. Main features of the selected village (Sherpur)

\begin{tabular}{|c|c|}
\hline Total Population & 1545 \\
\hline Total No of Houses & 260 \\
\hline Female Population \% & $47.6 \%(735)$ \\
\hline Total Literacy rate \% & $40.5 \%(626)$ \\
\hline Female Literacy rate & $14.6 \%(226)$ \\
\hline $\begin{array}{c}\text { Scheduled Tribes } \\
\text { Population \% }\end{array}$ & $0.1 \%(1)$ \\
\hline $\begin{array}{c}\text { Scheduled Caste } \\
\text { Population \% }\end{array}$ & $45.0 \%(696)$ \\
\hline $\begin{array}{c}\text { Working Population \% } \\
\text { Child (0 -6) Population } \\
\text { by 2011 }\end{array}$ & $337.30 \%$ \\
\hline $\begin{array}{c}\text { Girl Child (0 -6) } \\
\text { Population \% by 2011 }\end{array}$ & $46.9 \%(158)$ \\
\hline
\end{tabular}

Table-2. Electricity requirements of each category per day per household

\begin{tabular}{|c|c|c|c|c|}
\hline Appliances & Location & $\begin{array}{l}\text { Rich } \\
\text { Family }\end{array}$ & $\begin{array}{l}\text { Medium } \\
\text { Family }\end{array}$ & $\begin{array}{l}\text { Poor } \\
\text { family }\end{array}$ \\
\hline CFL & Kitchen & 15 Watt & 15 Watt & ------ \\
\hline LED & $\begin{array}{l}\text { Living } \\
\text { Room }\end{array}$ & 32 Watt & 32 Watt & ------ \\
\hline Bulb & & ----- & ---- & $\begin{array}{l}100 \\
\text { Watt }\end{array}$ \\
\hline Fan & & 80 Watt & 80 Watt & $\begin{array}{l}80 \\
\text { Watt }\end{array}$ \\
\hline TV & & $\begin{array}{l}120 \\
\text { Watt }\end{array}$ & ---- & ---- \\
\hline Total & & $\begin{array}{l}247 \\
\text { Watt }\end{array}$ & $\begin{array}{l}127 \\
\text { Watt }\end{array}$ & $\begin{array}{l}180 \\
\text { Watt }\end{array}$ \\
\hline
\end{tabular}

\section{Calculation for total energy requirement:}

$$
\mathbf{E v}=\mathrm{W} * \mathbf{h} * \mathbf{F} / \mathbf{1 0 0 0}
$$

From above tables,

Electricity required by rich family,

$\mathrm{W}_{1}=247$ watt

Electricity required by medium family,

$\mathrm{W}_{2}=127$ watt

Electricity required by poor family,

$\mathrm{W}_{3}=180$ watt

Load operating hours per day, $\mathrm{h}=6$ hours (assumed)

$\begin{array}{lc}\text { No. of rich family, } & \mathrm{F}_{1}=38 \\ \text { NO. of medium family, } & \mathrm{F}_{2}=285 \\ \text { No. of poor family, } & \mathrm{F}_{3}=298\end{array}$

$$
\begin{aligned}
& \text { For rich family } \\
& \begin{aligned}
\text { Ev1 } & =(247 \times 6 \times 38) / \text { day } \\
& =56.31 \mathrm{kwh} / \text { day }
\end{aligned}
\end{aligned}
$$

For medium family

$$
\begin{aligned}
\text { Ev2 } & =(127 \times 6 \times 285) / 1000 \\
& =217.17 \mathrm{kwh} / \text { day }
\end{aligned}
$$

\section{For poor family}

Ev3 $=(180 \times 6 \times 298) / 1000$

321.84

Therefore, total energy requirement for village/day can be estimated as

$$
\begin{array}{rrr}
\mathrm{Ev} & = & \mathrm{Ev}_{1}+\mathrm{Ev}_{2}+\mathrm{Ev}_{3} \\
& = & 56.31+217.17+321.84 \\
= & \mathbf{5 9 5 . 1 4} \mathbf{~ k w h} / \text { day }
\end{array}
$$

Table - 3. Specific $\mathrm{CO}_{2}$ emission factor for three sources [4]

\begin{tabular}{|c|c|c|}
\hline Source & $\begin{array}{c}\text { Specific } \mathrm{CO}_{2} \\
\text { emissions factor } \\
(\beta) \text { in }(\mathrm{kg} / \mathrm{kwh}\end{array}$ & $\mathrm{CO}_{2}$ Savings \\
\hline Coal & 0.98 & 0.00 \\
\hline Oil & 0.77 & 0.00 \\
\hline PV System & 0.00 & $0.98 / 0.77$ \\
\hline
\end{tabular}

Calculation for $\mathrm{CO}_{2}$ emissions and saving: [5]

For coal-based system:

- When coal-based electricity is using for whole 365 days,

$$
\begin{array}{lll}
\mathrm{CO}_{2} \text { emissions } & \text { (tons/year) }=\mathrm{D}^{*} \mathrm{Ev}^{*} \beta \quad / 1000 \\
= & =(365 \times 595.14 \times 0.98 / 1000) \\
= & 212.88 \text { ton/year }
\end{array}
$$

- When Pv based electricity is using for 300 days \& coal based only for 65 days

$\mathrm{CO}_{2}$ emission (ton/year) $=\mathrm{D}^{*} \mathrm{Ev}^{*} \beta / 1000$ 


$$
\begin{aligned}
& =(65 \times 595.14 \times 0.98 / 1000) \\
& =37.91 \text { ton/year }
\end{aligned}
$$

CO2 saving $=(212.88-37.91)$

$$
=174.97 \text { ton/year }
$$

Since solar cell has a life span of 25 years.

Therefore in 25 years a village can save the $\mathrm{CO}_{2}$ $=174.97 \times 25$

$=4374.24$ ton

For oil-based system:

- When oil-based electricity is using for whole 365 days, $\mathrm{CO}_{2}$ emission (ton/year) $=\mathrm{D}^{*} \mathrm{Ev}^{*} \beta / 1000$

$$
\begin{aligned}
& =(365 \times 595.14 \times 0.77 / 1000) \\
& =167.26 \text { ton/year }
\end{aligned}
$$

\section{PROJECT COST}

Module Cost: Ministry of New and Renewable Energy (MNRE) Government of India is also promoting solar PV system under the Jawaharlal Nehru National solar mission in the country. They also provide subsidy of people solar panel under the scheme MNRE provide 30\% capital subsidy on capital expenditure for both commercial and residential entities for system up to $100 \mathrm{Kw}$.

Good ones manufacture in India would come as low as Rs. 3032 per Watt generated (when sold in bulk quantity)

Battery Cost: The cost of $180 \mathrm{Ah}$ Batteries (Exide) is Rs. 10000 (Approx.) in Indian market.

Inverter Cost: The cost of 400 VA Inverter (Microtek UPS) is Rs. 3800 (Approx.).

\section{Calculation of economic feasibility: [6]}

Life of stand-alone PV module $=25$ years

Per day working time of stand-alone PV system $=6 \mathrm{hrs}$

Per unit of electricity in Sherpur

$=$ Rs. 3.5/unit

\section{When stand-alone PV system is not used}

Electricity bill of 25 years will be

(i) For Rich family

Electricity bill $=247 * 6 * 365 * 25 * 3.5 / 1000$

$$
=\text { Rs. } 47331
$$

(ii) For Medium family

Electricity bill $=127 * 6 * 365 * 25 * 3.5 / 1000$

$$
=\text { Rs. } 24336
$$

(iii) For Poor family

Electricity bill $=180 * 6 * 365 * 25 * 3.5 / 1000$

$$
=\text { Rs. } 34492
$$

When stand-alone PV system is used

(i) For Each Rich family

Power requirement $=247 \mathrm{Watt} / \mathrm{day}$

Module cost/Watt output = Rs. 31/Watt output

No. of batteries required $\quad=3$

No. of inverters required $\quad=2$

Subsidy $\quad=30 \%$

Electricity bill for 25 years $=$ Rs. 47331

Total module cost $31 * 247=$ Rs. 7657

Total batteries and inverter cost $=3 * 10000+2 * 3800=$ 37600

Total cost $=7657+(37600 * 0.70)=$ Rs. 33977

So, installation cost of stand-alone PV system is lesser (Rs.33 977) as compare to electricity bill of 25 years (Rs.47331).

So, it is feasible to install stand-alone PV system in the rich family.

\section{(ii) For Each Medium family}

Power requirement $\quad=127 \mathrm{Watt} / \mathrm{day}$

Module cost/Watt output = Rs. 31/Watt output

No. of batteries required $\quad=2$

No. of inverters required $\quad=1$

Subsidy $\quad=30 \%$

Electricity bill for 25 years $=$ Rs. 24336

Total module cost $31 * 127=$ Rs. 3937

Total batteries and inverter cost $=2 * 10000+1 * 3800=$ Rs. 23800

Total cost $=3973+(23800 * 0.7)=$ Rs. 20597

So, the installation cost of stand-alone PV system is lesser

(Rs.20597) as compare to electricity bill of 25 years

(Rs.24336).

So, it is feasible to install stand-alone PV system in medium class family.

\section{(iii) For Each Poor family}

Power requirement $\quad=180 \mathrm{Watt} /$ day

Module cost/Watt output = Rs. 31/Watt output

No. of batteries required $\quad=2$

No. of inverters required $\quad=1$

Subsidy $\quad=30 \%$

Electricity bill for 25 years = Rs. 34492

Total module cost $31 * 180=$ Rs. 5580

Total batteries and inverter cost $=2 * 10000+1 * 3800=$ Rs. 23800

Total cost $=5580+(23800 * 0.7)=$ Rs. 22240

So, installation cost of stand-alone PV system is lesser

(Rs.22240) as compare to electricity bill of 25 years

(Rs.34492).

So, it is feasible to install stand-alone PV system in poor class family. 


\section{CONCLUSION}

Our requirement energy is increasing continuously with increasing population. It is not possible to reduce energy consumption the only feasible alternative is to increase the energy supply. This requires action on at least to fronts rationalization of every energy prices to provide incentive for promoting efficiency and secondary suggestion other initiative (not related to price) to push the economy towards greater energy efficiency. The use of super critical and ultras super critical technology in power generation can reduce the coal requirement for the electricity production. Shift in modes of transport from roads towards railways (in the case of freights) greater use of public transport in cities, and use of inland water transport can also make a significant difference in total energy use. In the context of the declared goal of energy for all, if the required energy is generated from fossil fuels, the level of greenhouse gasses and other pollutant will rise enormously. To keep the environment relatively pollution free and to full fill the energy demands, the use of renewable resources is a better choice. Thus, continued emphasis is to be placed on renewable resources, especially on expanding wind power generation and it is promoting solar thermal and solar photovoltaic alternative. Government of India is promoting the use of solar utility by providing heavy subsidies on various solar appliances in rural as well as urban areas. On many asserts that renewable sources of energy are conducive to cleaner and environment and constitute a wise and economical choice.

\section{References}

[1]. INDIA GDP: 9,634 TRILLION INTERNATIONAL DOLLARS (2018) GROSS DOMESTIC PRODUCT (PPP IN 2011 PRICES)

[2]. censusindia.gov.in, Census_Data_2001, Series/Number_of_Village.

[3]. United States Environmental Protection Agency

[4]. wikipedia.org/wiki/Solar_power_in_India

[5]. sites.lafayette.edu/egrs352-sp14-pv-technology

[6]. Article in Advances in Building Energy Research Volume 3(No. 3) - September 2015 with 24 Reads DOI: 10.12989/eri.2015.3.3.157

[7]. Solar Energy,Vol. 70, No. 4, pp. 349-359, 20012001 Elsevier Science Ltd 